\title{
Opprimo ergo sum-Evasion and Suppression in the Root Endophytic Fungus Piriformospora indica
}

\author{
Urs Lahrmann and Alga Zuccaro \\ Max Planck Institute for Terrestrial Microbiology-Organismic Interactions, Marburg, Germany
}

Submitted 15 November 2011. Accepted 1 February 2012.

\begin{abstract}
The genetically tractable endophytic fungus Piriformospora indica is able to colonize the root cortex of a great variety of different plant species with beneficial effects to its hosts, and it represents a suitable model system to study symbiotic interactions. Recent cytological studies in barley and Arabidopsis showed that, upon penetration of the root, $P$. indica establishes a biotrophic interaction during which fungal cells are encased by the host plasma membrane. Large-scale transcriptional analyses of fungal and plant responses have shown that perturbance of plant hormone homeostasis and secretion of fungal lectins and other small proteins (effectors) may be involved in the evasion and suppression of host defenses at these early colonization steps. At later stages, $P$. indica is found more often in moribund host cells where it secretes a large variety of hydrolytic enzymes that degrade proteins. This strategy of colonizing plants is reminiscent of that of hemibiotrophic fungi, although a defined shift to necrotrophy with massive host cell death is missing. Instead, the association with the plant root leads to beneficial effects for the host such as growth promotion, increased resistance to root as well as leaf pathogens, and increased tolerance to abiotic stresses. This review describes current advances in understanding the components of the $P$. indica endophytic lifestyle from molecular and genomic analyses.
\end{abstract}

Plant mutualistic fungi play a key role in shaping terrestrial ecosystems. This function is not restricted to the better characterized arbuscular mycorrhizal (AM) or ectomycorrhizal (ECM) fungi; however, there is also growing evidence that cryptic rootassociated fungal taxa are important determinants of the distribution and abundance of plant species (Rosling et al. 2011). In particular, root endophytic associations, which lack a specialized interface formed by complex hyphal growth, can be of mutualistic nature. Inter- or intracellular colonization by this group of fungi is often extensive and limited to the epidermis or cortex cells (Brundrett 2006; Rodriguez and Redman, 2008; Rodriguez et al. 2009; Schulz 2006; Schulz and Boyle 2005). Many root endophytes are loosely associated with a wide variety of plant species and can additionally exploit their saprotrophic capability in order to survive in the soil. The order Sebacinales, which is presently recognized as the earliest diverging lineage of mycor-

Corresponding author: A. Zuccaro;

E-mail: zuccaro.alga@mpi-marburg.mpg.de

* The $\boldsymbol{e}$-Xtra logo stands for "electronic extra" and indicates that Figures 3 and 4 appear in color online. rhizal Basidiomycota, harbors a broad spectrum of mycorrhizal types, ranging from ECM, ericoid (EM), and orchid mycorrhizal (OM) to root endophytes (Basiewicz et al. 2011; Deshmukh et al. 2006; Matheny et al. 2007; Weiss et al. 2004, 2011). The basal taxa in the order Sebacinales, which comprehend the axenically cultivable root endophytes Sebacina vermifera complex, Piriformospora williamsii, and $P$. indica, possess pronounced saprotrophic characteristics (Basiewicz et al. 2011; Deshmukh et al. 2006; Waller et al. 2008; Warcup 1988; Warcup and Talbot 1966, 1967; Weiss et al. 2004, 2011; Williams 1985). Derived species in this order are thought to be obligate biotrophic symbionts, with no cultures available at the present time. Therefore, mutualistic symbiosis in the form of obligate biotrophy might be derived from saprotrophic ancestors in the order Sebacinales (Basiewicz et al. 2011; Matheny et al. 2007; Weiss et al. 2011; Zuccaro et al. 2011). Comparative analysis of the recently sequenced $P$. indica genome with other genomes of Basidiomycota and Ascomycota fungi that have diverse lifestyle strategies identified several features typically associated with saprotrophy or with biotrophy. $P$. indica, which was originally isolated in association with a spore of Glomus mosseae from the rhizosphere of two shrubs in the Indian Thar desert, is the asexual model organism for experimental studies in the order Sebacinales (Verma et al. 1998). This symbiotic fungus displays an endophytic lifestyle and has the ability to colonize the root cortex cells of a wide range of mono- and dicotyledonous plants, displaying a broad range of beneficial effects to the host (Baltruschat et al. 2008; Sherameti et al. 2005, 2008; Sun et al. 2010; Vadassery et al. 2009; Waller et al. 2005; Yadav et al. 2010). The maintenance or enforcement of saprotrophic traits and the implementation of biotrophic characteristics have possibly led to the broad distribution of sebacinoid fungi in a wide range of plant species (Basiewicz et al. 2011; Weiss et al. 2011). Therefore, these extant basal transition forms of non-host-specific root endophytes with marked saprotrophic characteristics could play a more significant role in natural and managed ecosystems and in evolution of land plants than previously thought. Understanding the colonization strategies and the mechanisms involved in beneficial effects conferred to the plant hosts in this class of fungi could help to clarify the evolutionary steps involved in mycorrhizal symbiosis. Recent findings have begun to shed light on the molecular mechanisms underlying this symbiosis and will be discussed in this review, with particular focus on plant defense suppression and fungal genomic traits.

Growth promotion by $\boldsymbol{P}$. indica.

The positive effects of $P$. indica colonization on a broad range of plant hosts suggest that the beneficial outcome may be based on general mechanisms and signaling pathways common 
to most if not all plant roots (Camehl et al. 2011; Deshmukh et al. 2006; Fakhro et al. 2010). One such signaling pathway was recently reported in Arabidopsis to be mediated by the 3-phosphoinositide-dependent protein kinase 1 (PDK1) and the serine/ threonine protein kinase oxidative signal inducible 1 (OXI1) (Camehl et al. 2011) (Fig. 1). These protein kinases were shown to play a key role in the convergent lipid signaling (via phosphatidic acid [PA]) and oxidative stress signaling (via $\mathrm{H}_{2} \mathrm{O}_{2}$ ) in Arabidopsis roots (Anthony et al. 2006; Hirt et al. 2011; Rentel et al. 2004). OXI1 is a member of the AGC family of protein kinases and is critical for basal resistance to $\mathrm{Hy}$ aloperonospora arabidopsidis (formerly Peronospora parasitica) infection and root hair growth by two different reactive oxygen species (ROS)-mediated processes (Anthony et al. 2004; Rentel et al. 2004). PDK1 acts upstream of OXI1 and other AGC kinases and regulates diverse signaling pathways, including auxin signaling and cell death (Devarenne et al. 2006; Zegzouti et al. 2006) (Fig. 1). Mutation of either Arabidopsis OXI1 or PDK1 kinases resulted in loss of growth response to Piriformospora indica, demonstrating the importance of this

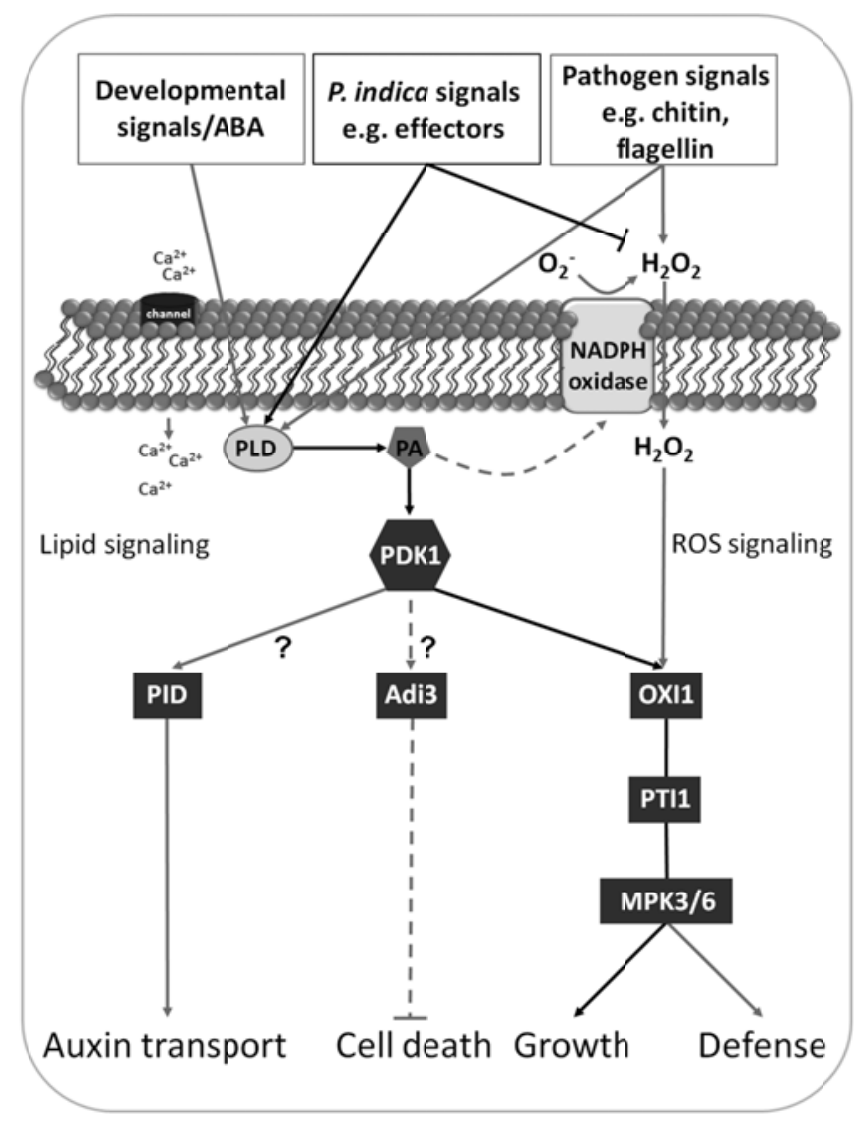

Fig. 1. Proposed role of 3-phosphoinositide-dependent protein kinase 1 (PDK1) in mediating symbiosis in the Piriformospora indica-Arabidopsis system. PDK1 and serine/threonine protein kinase oxidative signal inducible 1 (OXI1) kinases play a key role in the convergent lipid signaling (via phosphatidic acid [PA]) and oxidative stress signaling (via $\mathrm{H}_{2} \mathrm{O}_{2}$ ) in Arabidopsis. The root endophyte $P$. indica suppresses production of $\mathrm{H}_{2} \mathrm{O}_{2}$ and activates OXI1 via the phosphatidic acid (PA)-activated PDK1. This leads to growth promotion and seems to be in contrast to pathogens which activate both lipid and reactive oxygen species (ROS) signaling (Camehl et al. 2011; Hirt et al. 2011; Jacobs et al. 2011). Negative cell-death regulation is initiated by PDK1 phosphorylation of Adi3 in tomato. A homologue of Adi3 exists in Arabidopsis (AGC1-3) but its function has not yet been characterized (Devarenne et al. 2006; Ek-Ramos et al. 2010). Activation of PID in Arabidopsis results in targeted localization of the polar auxin transport (Zegzouti et al. 2006). Whether or not the downstream PID and Adi3 pathways are activated via OXI1 during interaction of $P$. indica with Arabidopsis is unknown. ABA = absissic acid, PLD = phospholipase D. signaling pathway in the mutualistic interaction. In Arabidopsis, two closely related PDK1 kinases are present, PDK1.1 and PDK1.2, which seem to have a redundant activity. Conceivably, only the double mutants were impaired in the response to $P$. indica (Camehl et al. 2011). Due to induction of gene expression for OXI1 and both PDK1 kinases, and stimulation of PA but not ROS production by the beneficial fungus, Camehl and associates (2011) concluded that the OXI1 kinase is not activated by oxidative stress $\left(\mathrm{H}_{2} \mathrm{O}_{2}\right)$ but by PA-activated PDK1 in this system (Camehl et al. 2011; Hirt et al. 2011; Jacobs et al. 2011). Endogenous developmental signals in plants which lead to the activation of the lipid signaling pathway are not necessarily coupled to ROS production (Wang 2005). In contrast to pathogens which induce both ROS and lipid signaling pathways (Anthony et al. 2006; Hirt et al. 2011), Arabidopsis response to $P$. indica colonization strongly resembles plant response to developmental signals. One could speculate that $P$. indica recruitments of the PA-mediated PDK1 activation mimics plant endogenous signals resulting in growth promotion in Arabidopsis. PA-mediated signal transduction includes cytoskeleton rearrangement, modulation of receptor signaling, and vesicle trafficking during endocytosis or exocytosis (Wang et al. 2006). PA accumulation can be triggered by two different pathways, via phospholipase $\mathrm{D}$ or via phospholipase $\mathrm{C}$, in response to many different stresses. Potential mediators in the PDK1 activation include the phytohormone absissic acid (ABA), oxidative stress, and exposure to microbial pathogens or pathogen-derived elicitors, such as cell wall fragments or highly specific pathogen-secreted proteins such as the Cladosporium fulvum elicitor protein Avr4 and the 22-kDa fungal ethylene-inducing xylanase (EIX) (Boller 1995; Boller and Felix 2009; de Jong et al. 2004; Laxalt et al. 2001; Testerink and Munnik 2005; van der Luit et al. 2000; Wang et al. 2006; Yamaguchi et al. 2005). A variant of this latter enzyme lacking $\beta$-1-4-endoxylanase activity was still able to induce a defense response in plants (Furman-Matarasso et al. 1999). The surfaceexposed epitope TKLGE pentapetide of EIX was shown to be responsible for the pathogen-associated molecular pattern (PAMP) immune response (Rotblat et al. 2002). Anthony and associates (2006) showed that PDK1 was activated in Arabidopsis protoplasts exposed to xylanases. This result indicates that, as in tomato and tobacco, the enzyme itself could work as a proteinaceous elicitor of PDK1 in Arabidopsis. The elicitors responsible for the activation of PDK1 in the $P$. indica-Arabidopsis symbiosis are not known. During colonization of barley, several genes encoding for xylanases belonging to glycoside hydrolase families 10 (GH10) and 11 (GH11) were upregulated in $P$. indica (Zuccaro et al. 2011), suggesting that these proteins or the oligosaccharides released by their activities could be involved in activation of PDK1. More work in this area is required to determine which $P$. indica elicitors are involved in the activation of plant pathways involved in growth promotion.

\section{Broad plant defense suppression.}

Plant-inhabiting microbes have evolved specific features to overcome chemical and physical host barriers in order to survive and gain advantages from the colonized host. By overcoming host barriers, plant-associated microorganisms often cause perturbations which may be recognized by the innate immune system of the host. The main function of this system is to detect and ward off potentially dangerous microbes such as fungal and bacterial pathogens. The first layer of this system is based on perception of PAMPs or microbe-associated molecular patterns (MAMPs) or on perception of cell components released during cell damage through pattern recognition receptors (PRR). These receptors are able to perceive conserved molecular signatures, such as chitin and chitosan for fungi and 
flagellin and elongation factor Tu for bacteria, which are characteristic for microbes but are absent from the host (Boller 2009; Zipfel 2009). Without specific mechanisms to avoid the plant innate immune system, plant-associated microbes are quickly detected and eventually stopped. Colonization in this instance reflects the ongoing evolution between plant-associated microbes and their host, where colonization is the result of a microbial adaptive strategy for survival. Successful microbes, therefore, must possess inherent ways to avoid, evade, or subvert the immune response and reprogram host metabolism to serve their own needs. As part of the establishment of the biotrophic lifestyle, $P$. indica was shown to be able to repress $\mathrm{H}_{2} \mathrm{O}_{2}$ accumulation in the roots and actively suppress immune responses triggered by various MAMPs (Camehl et al. 2011; Jacobs et al. 2011). The adaptive strategy, or lifestyle, for broad immune system evasion and suppression appears distinctive to biotrophic fungi, independently from the nature (pathogenic or mutualistic) of their interaction (Brefort et al. 2009; Garcia-Garrido and Ocampo 2002). These capabilities represent a fundamental requirement for a long-term hostmicrobe interaction. The initial transient and weak defense response to $P$. indica during barley biotrophic colonization, observed by global transcriptional analysis of plant genes (Schäfer et al. 2009), suggests that the plant recognizes $P$. indica. At this early stage, production of papillae could be observed at sites where hyphal tips of $P$. indica attempted to penetrate cortical root cells in barley (Fig. 2). This transient phenomenon correlates well with the biotrophic phase (Zuccaro et al. 2011). Altogether, these observations indicate that, upon $P$. indica recognition by the host, a nonspecific plant response is induced. Once the fungus has entered the root cortex cells, a biotrophic interface is established and plant defense responses are suppressed. It is reasonable to assume that $P$. indica's remarkable capacity for root colonization of a wide host spectrum depends on the evolution of strategies for general compatibility which target conserved recognition and signaling pathways in roots. One such strategy could be targeting chemical reactions involved in ROS and NO production in plants by blocking either the activity of key enzymes (i.e., NADPH oxidase) or the signals leading to their activation (i.e., PRR and their signaling partners), as described for phytopathogenic prokaryotes (Hann et al. 2010). The challenge to come will be to link these processes with specific $P$. indica effectors and to elucidate their function in the establishment of a compatible relationship with roots.

\section{Recruitment of phytohormone pathways by $\boldsymbol{P}$. indica.}

Recently emerging models suggest that production of phytohormones or phytohormone-mimics and hijacking host hormone biosynthetic pathways are common colonization strategies used by both necrotrophic as well as biotrophic microorganisms (Depuydt and Hardtke 2011; Pieterse et al. 2009; RobertSeilaniantz et al. 2011). For instance, the necrotrophic fungus Botrytis cinerea is able to produce the phytohormones ABA and cytokinin (CK), and the biotrophic corn smut fungus Ustilago maydis produces auxin during colonization of maize leaves and induces host auxin synthesis and signaling during tumor formation (Brefort et al. 2009; Tudzynski and Sharon 2002). The biotrophic bacterial pathogen Pseudomonas syringae pv. tomato induces plant auxin and ABA production upon effector delivery, resulting in attenuated host basal defense responses and enhanced bacterial growth (de Torres-Zabala et al. 2007; Pieterse et al. 2009). Piriformospora indica was shown to be able to produce auxin and CK, whereas jasmonic acid (JA) and ABA were not detected in the culturing medium (Sirrenberg et al. 2007; Vadassery et al. 2008). Although, in Arabidopsis, auxin levels and the expression of auxin-regulated genes are not altered in $P$. indica-colonized roots (Vadassery et al. 2008), the auxin level in infected Chinese cabbage roots (Lee et al. 2010) and infected barley roots at the early colonization phase (M. Zurawska, L. M. Voll, and A. Zuccaro, unpublished data) is higher. The implication of hormonal plant growth regulators in innate immunity establishes a link between plant development and defense. As seen for the PDK1 and OXI1 kinases, which play a role in the convergent lipid and ROS signaling, the interconnection of cross-communicating hormone-signaling pathways was shown to be recruited by $P$. indica for manipulation of plant defense and development for JA (Camehl et al. 2010; Molitor and Kogel 2009; Stein et al. 2008) auxin (Lee et al. 2011; Sirrenberg et al. 2007; Vadassery et al. 2008), ethylene (Camehl and Oelmüller 2010; Camehl et al. 2010; Molitor and Kogel 2009), and CK (Vadassery et al. 2008). Transcriptional analysis of plant responses to colonization of barley by $P$. indica is accompanied
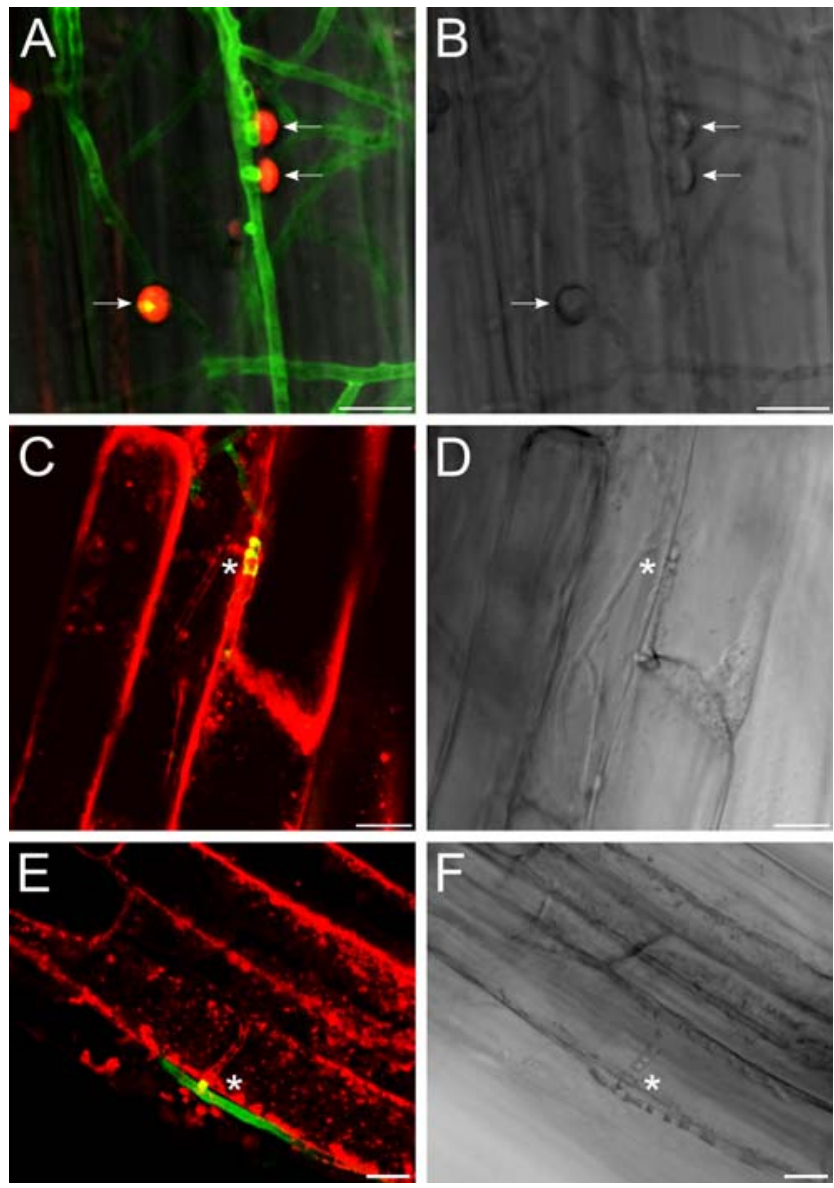

Fig. 2. Biotrophic lifestyle of Piriformospora indica in barley and Arabidopsis root cortex cells. A, Papillae formation upon fungal penetration attempts in barley cortex cells (white arrows). Fungal hyphae were stained with WGA Alexa Fluor and papillae were stained with Con-A. B, Bright field. C, Living barley root cortex cells with fungal hyphae inside (4 days postinoculation). Fungal structures were stained with WGA Alexa Fluor 488 conjugate (green) and plant membranes were stained with FM4-64 (red). D, Bright field E, Living Arabidopsis root cortex cells with fungal hyphae inside (4 days postinoculation). Fungal structures were stained with WGA Alexa Fluor 488 conjugate (green) and plant membranes were stained with FM4-64 (red). F, Bright field. In contrast to extracellular hyphae, intracellular hyphae are not stainable with WGA Alexa Fluor 488 due to the fact that the hyphae remain enveloped in a plant-derived membrane throughout intracellular growth. Internalization of FM4-64 in the form of endomembrane structures after $20 \mathrm{~min}$ of incubation are visible inside the plant cell, indicating viability of the cells. Pictures were taken by confocal laser microscopy, Leica TCS SP5. White asterisks indicate the site of penetration. 
by induction of genes involved in ABA and auxin pathways during biotrophy, and gibberellic acid (GA) and brassinosteroid during the cell-death-associated phase (Schäfer et al. 2009) (Fig. 3). Plant mutants impaired in GA and JA metabolism proved to be less susceptible to colonization by $P$. indica and displayed an increased root immune response to the fungal symbiont (Jacobs et al. 2011; Schäfer et al. 2009). On the other side, Arabidopsis mutants impaired in salicylic-acidassociated defense are more susceptible to colonization by $P$. indica (Jacobs et al. 2011). These results hint toward manipulation of phytohormone homeostasis to sequentially suppress a range of host defense responses in defined temporal windows during the switch from biotrophy to the cell-death-associated phase (Fig. 3).

\section{$P$. indica karyotype.}

Ascomycota as well as Basidiomycota fungi have heterokaryotic life stages where genetically distinct nuclei inhabit the same cell. Heterokaryons can arise through mating of homokaryotic individuals of different nuclear types or, spontaneously, through mutation of one nucleus during somatic growth of a homokaryon. During the life cycle of Basidiomycota, the heterokaryotic phase is normally the dominant growth phase and might display indeterminate growth (James et al. 2008). Heterokaryosis has some evolutionary implications, such as an increased adaptive potential due to genetic variation between the different nuclei (Clark and Anderson 2004). When the heterokaryons undergo somatic recombination, a reshuffling of genes between nuclei may occur. The reshuffling of the genomes could create new genetic variants of the fungus that also differ in colonization and beneficial effects to the host (Gladfelter and Berman 2009). Most Agaricomycete species are dikaryons and possess two genetically distinct nuclei. Nevertheless, there is a considerable variation on the number of nuclei per cell in this group of fungi. For example, in Coprinopsis cinerea, the cells of dikaryotic mycelia are regularly binucleate and display clamp connections (Iwasa et al. 1998) whereas, in Agaricus bisporus, the cells are highly multinucleate and possess no clamp connections (Raper et al. 1972). Members of the order Sebacinales, including $P$. indica, have a variable number of nuclei per cell with no clamp connections (Basiewicz et al. 2011; M. Basiewicz, K. H. Kogel, and A.
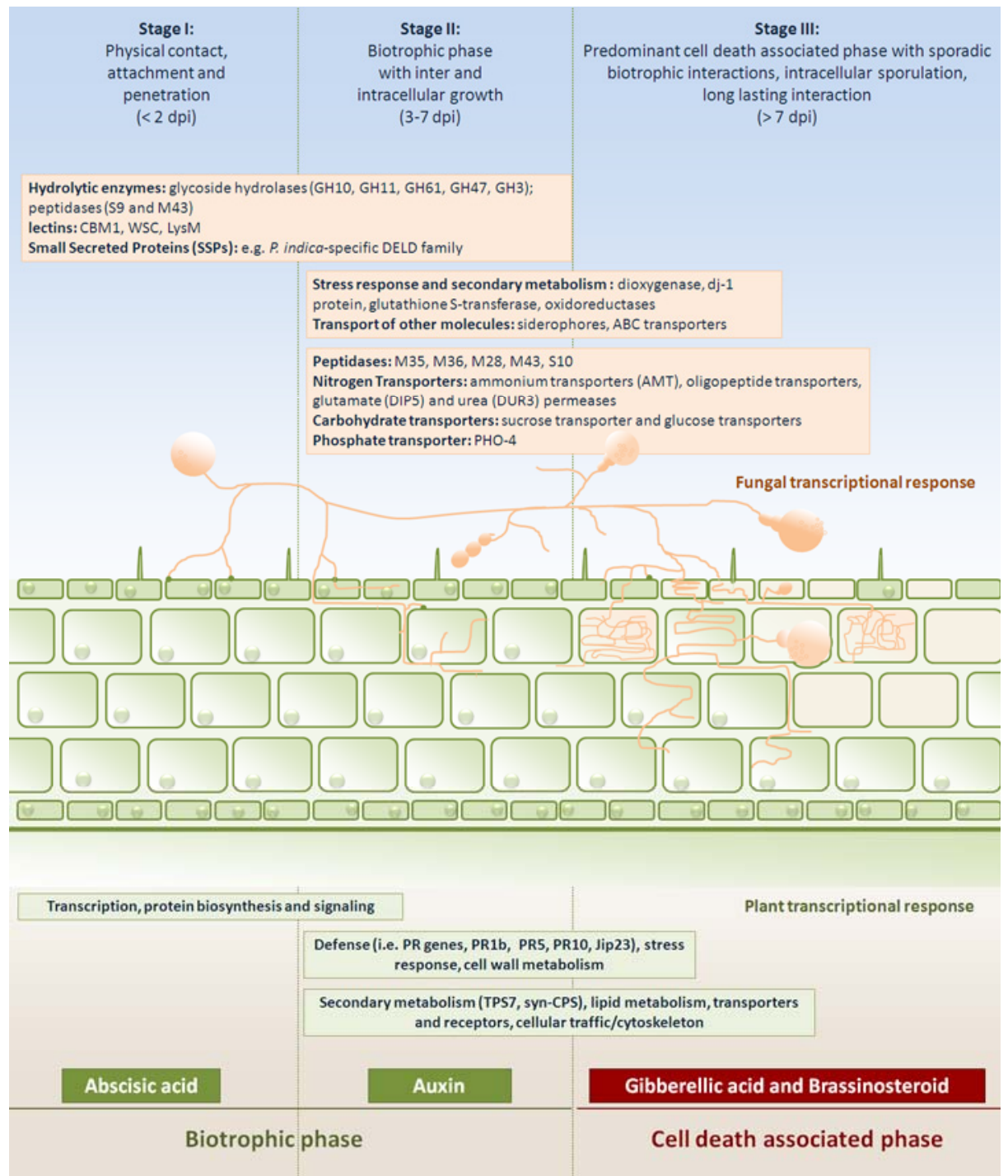

Fig. 3. Schematic summary of fungal and plant gene expression during colonization of barley roots by Piriformospora indica. Three characteristic stages (stage I and II = early and late biotrophic phase and stage III = cell-death-associated phase) of barley colonization by $P$. indica are shown with a time scale. Text boxes refer to fungal key genes (upper part) and typical plant responses (lower part) induced during barley colonization by $P$. indica in the respective stages. Plant hormones metabolism involved at the different stages is shown at the bottom of the figure. The fungal transcriptional response was described by Zuccaro and associates (2011) and the plant transcriptional response by Schäfer and associates (2009). 
Zuccaro, unpublished data). P. indica's genome size of approximately $25 \mathrm{Mbp}$ represents one of the smallest genomes among Basidiomycota (with average genome size of $52 \mathrm{Mbp}$ calculated from 426 genomes) (Fungal Genome Size database). This genome size is common to other members of the order Sebacinales, which display different karyotype profiles but genome sizes of 21 to $26 \mathrm{Mbp}$ (Basiewicz et al. 2011). Although no information about the life cycle of $P$. indica and other members of the order Sebacinales is available, the identification of two allelic mating type loci in the $P$. indica draft genome and single nucleotide polymorphisms (SNP) with two variants indicate that the sequenced strain of $P$. indica is most likely a heterokaryon containing two genetically distinct nuclei (Zuccaro et al. 2011). The presence of SNP with a ratio of $1: 1$ in the draft genome of $P$. indica (U. Lahrmann and A. Zuccaro, unpublished data) and the finding of multinucleate cells with a variable number of nuclei raise the question of whether nuclear ratio in this organism is a tightly controlled event. There is molecular communication between paired nuclei in a dikaryon and distance between nuclei has major consequences for gene expression (Gladfelter and Berman 2009; Schuurs et al. 1998). No information about this crosstalk and the regulation of downstream genes is available for the order Sebacinales. Now, the genetic tractability of $P$. indica could help to clarify some of these aspects in this group of symbiotic fungi (Yadav et al. 2010; Zuccaro et al. 2009).

\section{Genomic and transcriptomic traits.}

With just a few exceptions, such as those reported for some nonphotosynthetic vascular plants (Bidartondo et al. 2003), colonization of plants is beneficial for the fungus, ensuring nutrient supply and shelter from biotic and abiotic stresses. Far

Fig. 4. Comparison of proteins containing different domains involved in hydrolytic activity, secondary metabolites biosynthesis, and carbohydrate binding in Basidiomycota fungi. Shown is a selection of gene families which proved to be either expanded or contracted in Piriformospora indica based on comparative analyses (Zuccaro et al. 2011). Proteins of publically available genomes from Basidiomycota fungi were annotated using the Pfam database and results were screened for the presence of the belowlisted domains. The number of proteins containing either one of the indicated domains in relation to the total number of proteins of the respective organism (percentage of whole proteins) is shown in the graphic. A, Abundance of proteins containing one of the following enzymatic domains: esterase PHB depolymerase (Esterase_phd, PF10503); glyoxal oxidase Nterminus (Glyoxal_oxid_N, PF07250); fungalysin metallopeptidase (Peptidase_M36, PF02128); pregnancy-associated plasma protein-A (Peptidase M43, PF05572); glycoside hydrolase family 10 (Glyco_hydro_10, PF00331); glycoside hydrolase family 5 (Cellulase, PF00150); and glycoside hydrolase family 61 (Glyco_hydro_61, PF03443). B, Abundance of proteins containing one of the following domains characteristic for secondary metabolites biosynthesis: AMP-binding enzyme (AMP-binding, PF00501); phosphopantetheine attachment site (PP-binding, PF00550); condensation domain (Condensation, PF00668); NAD-dependent epimerase/ dehydratase family (Epimerase, PF01370); methyltransferase domain 11 (Methyltransf_11, PF08241); methyltransferase domain 12 (Methyltransf_12, PF08242); short-chain dehydrogenase (adh_short, PF00106); $\beta$ ketoacyl synthase, N-terminal domain (ketoacyl-synt, PF00109); KR domain (KR, PF08659); acyl transferase domain (Acyl_transf_1, PF00698); thioesterase domain (Thioesterase, PF00975); ferric reductase-like transmembrane component (Ferric_reduct, PF01794); 3- $\beta$ hydroxysteroid dehydrogenase/isomerase family (3ß_HSD, PF01073); male sterility protein (NAD_binding_4, PF07993); and bacterial transferase hexapeptide (six repeats) (Hexapep, PF00132). Note the absence of the condensation domain in $P$. indica draft genome which is required in the elongation or extending modules of a complete nonribosomal peptide synthetase. C, Abundance of proteins containing one of the following carbohydrate binding domains: lysin motif domain (LysM, PF01476); cell wall integrity and stress response component domain, (WSC, PF01822); and carbohydratebinding module 1 (CBM_1, PF00734). more difficult is to define the interaction between a plant and a fungus as mutualistic. There are several forms of symbioses, all of which differ from each other by nuances and form a continuum of interactions, from parasitic to beneficial. These nuances, although difficult to grasp, are important for understanding the individual symbiotic interaction and might be reflected in the genomic and transcriptomic traits. For instance, ECM fungi are dual soil-plant inhabitants that are efficient at deriving nutrients from both soils and plants. Thus, they display a strong adaptation to life within host cells but also encompass saprotrophic characteristics. AM fungi are obligate biotrophic

A

Hydrolytic activity

Glyco_hydro_61 $\square$ Cellulase $\square$ Glyco_hydro_10 $\square$ Peptidase_M43
$\square$ Peptidase_M36 $\square$ Glyoxal_oxid_N $\square$ Esterase_phd

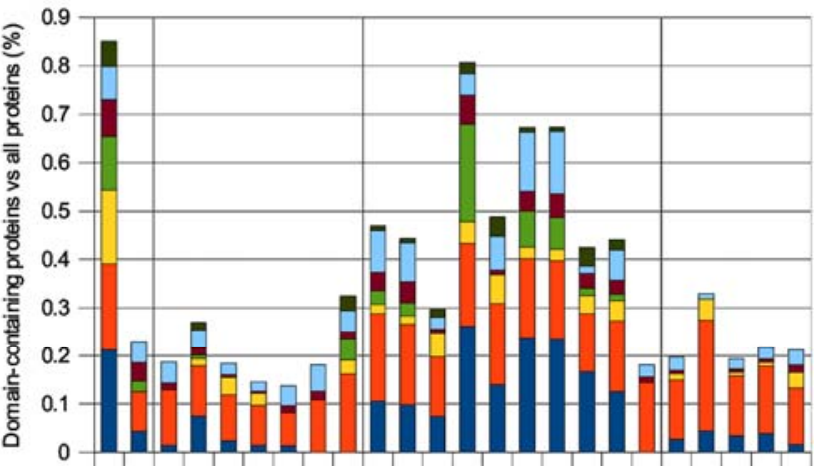

B Secondary metabolism
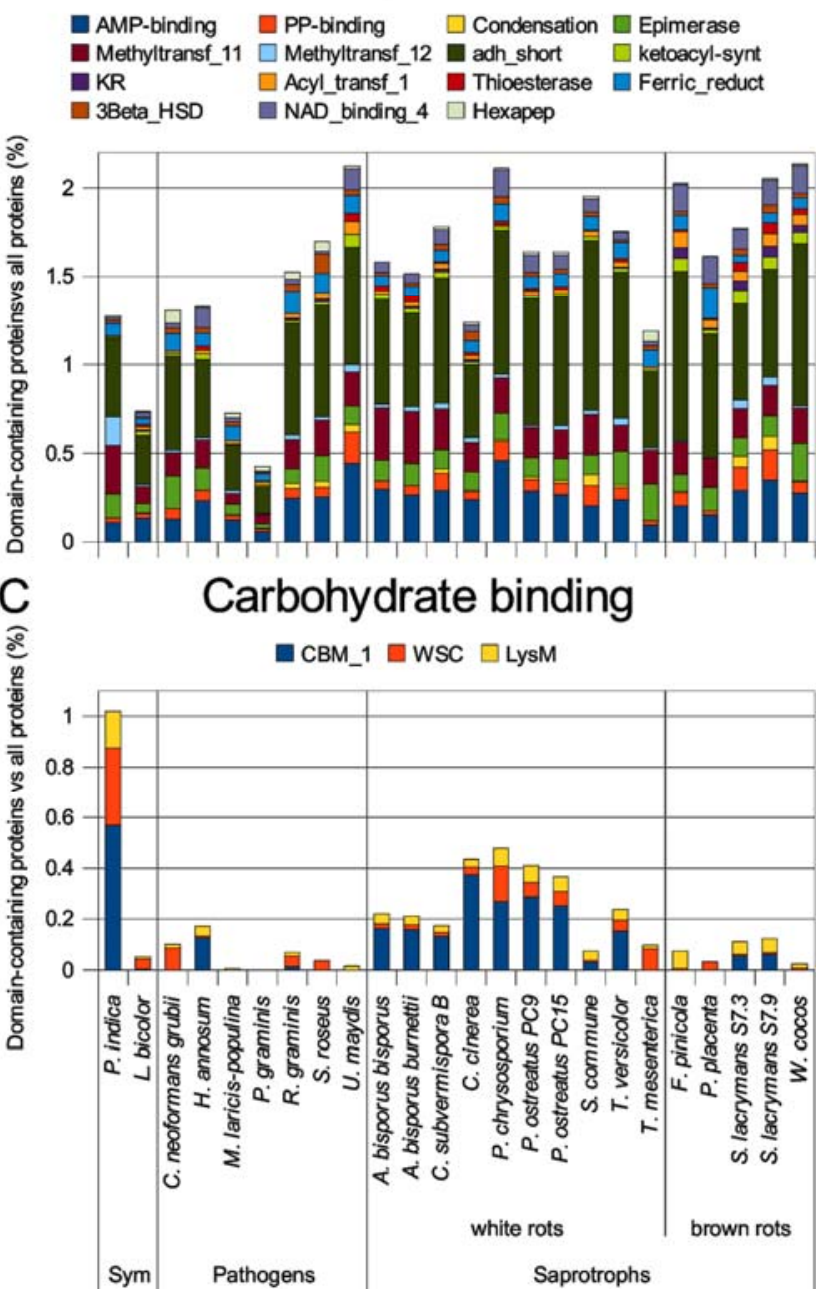
organisms which display no or very few saprotrophic capabilities. Similar to the ECM fungi, AM fungi have an efficient means of acquiring inorganic nutrients from soil to supply plants. Conversely, endophytes like $P$. indica and pathogens are thought to colonize the host without efficient means for nutrient transfer toward the plant. These aspects have strongly affected methods of analyzing fungal genomes. Although genomics of mycorrhizal fungi has focused largely on transporters (e.g., hexose and phosphate transporters), this information is, at present, secondary in plant pathogenomics. Only recently has emphasis been given to hexose/sucrose transporters in plant pathosystems (Wahl et al. 2010). The nutritional strategies and mode of nutrient uptake in the endophytic fungal category are largely unknown. Comparative analysis of the $P$. indica genome with other genomes of fungi that have diverse lifestyles identified numerous features typically associated with saprotrophy. These included, among others, expansion of gene families encoding hydrolytic enzymes (e.g., metallopeptidases and cell-wall-degrading enzymes [CWDE]) (Fig. 4A). Saprotrophic characteristics are thought to represent ancestral traits. Indeed, mutualism between fungi and plant roots has arisen independently several times from saprotrophic ancestors (Hibbett and Matheny 2009; Plett and Martin 2011). Recently, it has been demonstrated by phylogenomic analysis of gene families encoding plant CWDE that ectomycorrhizal biotrophy emerged from white rot ancestry and is accompanied by reduction or complete losses in glycoside hydrolases and peroxidases families and by expansion of pectinases and hemicellulases, suggesting adaptation to colonization of living plant cells (Eastwood et al. 2011). Analysis of expanded gene families indicates that $P$. indica's hydrolytic machinery, including proteases and cell wall hydrolases, is similar to that of white rot saprophytes (Fig. 4A). Global transcriptional responses associated with the colonization of living and dead barley roots by $P$. indica showed a tightly controlled expression of the lifestyle-associated gene sets during the onset of the symbiosis. Colonization of living barley roots was accompanied by changes in expression of genes encoding for GH10, GH11, and GH61 which, therefore, seem to play an important role in symbiosis (Zuccaro et al. 2011). The expression of these genes was induced during first physical contact and early biotrophic colonization ( 2 and 3 days postinoculation). This changed at progressed colonization stages ( 5 days postinoculation), where just a few CWDE were induced. At this later biotrophic phase, a dramatic upregulation of $P$. indica transcripts coding for genes involved in protein hydrolysis and transport suggest that these genes might play a role in nutrient acquisition during growth in planta (Zuccaro et al. 2011). Extracellular fungal proteases have been implicated in different functions, spanning from adherence to degradation of cell wall and host cells for nutrient acquisition. Although protease gene family expansion has been suggested to be related to pathogenesis, saprophytes also possess a high number of peptidases (Burmester et al. 2011; Joneson et al. 2011; Lilly et al. 2008; Stajich et al. 2010) (Fig. 4A). As reported for Mycosphaerella graminicola (Goodwin et al. 2011), expression of extracellular proteases and metallopeptidases could represent a different nutritional strategy where, instead of the usual carbohydrate metabolism, nutritional demands may be satisfied by protein degradation during the switch to the cell-death-associated phase. To which extent nitrogen availability affects the onset of $P$. indica symbiosis with plant roots and the switch to the cell-death-associated phase needs to be clarified.

In addition to saprotrophic features, unmistakable biotrophic hallmarks were identified in the $P$. indica draft genome, such as a large repertoire of small secreted proteins (SSP $<300$ amino acids), impaired nitrogen reduction and assimilation, and absence of key genes involved in the production of secondary metabolites via nonribosomal peptide synthetases and polyketide synthase (Fig. 4B). Some of these features are mirrored in the genomes of obligate biotrophic pathogens, such as that of rust fungi and powdery mildew fungi, indicating convergent adaptation to a life inside living host cells (Duplessis et al. 2011; Spanu et al. 2010).

\section{Effector-like molecules in $\boldsymbol{P}$. indica.}

Although it is established that most phytopathogenic fungi are able to reprogram plant defense and cell metabolism through the secretion of small protein effectors, it has been shown only recently that such effector-like proteins exist in mutualistic fungi (Plett et al. 2011; Kloppholz et al. 2011). Current transcriptional analysis has provided first insights into $P$. indica's colonization strategies. These include the in planta expression of a high number of lectins and $P$. indica-specific SSP. These proteins represent approximately $10 \%$ of the plantinduced genes during the early biotrophic colonization of barley. In analogy to other fungi where effector genes are upregulated during host colonization, the increased level of expression of $P$. indica genes encoding SSP suggests that these proteins are likely to play a role in determining the success of endophytic interaction, which involves host cell penetration, suppression of plant immunity, and growth within living cells. Some of the plant-responsive SSP from $P$. indica are cysteine rich, as described for other effector molecules in mutualistic and pathogenic systems (Duplessis et al. 2011; Hacquard et al. 2011; Spanu et al. 2010; Stergiopoulos and de Wit 2009), and others possess distinctive features such as a regular pattern of histidine and alanine residues (Zuccaro et al. 2011). A search for motifs in the amino acid sequence of $P$. indica histidineand alanine-rich proteins identified a highly conserved pattern of seven amino acids, "RSIDELD", at the C-terminus (designated DELD proteins). The conservation of this motif in the putative DELD effector family suggests a common functional role, possibly in effector delivery into the plant cytoplasm or in binding to host substrates, as was suggested for other conserved motifs (e.g., Y/F/WXC) at the N-terminus of barley powdery mildew (Godfrey et al. 2010; Spanu et al. 2010). The DELD proteins have a similar size, between 100 and 130 amino acids, and no known functional protein domains were detected. Protein homology searches with the central part of these proteins revealed approximately $30 \%$ similarity to HRPII, a well-studied effector protein family from Plasmodium falciparum. HRPII was reported to be localized in several host cell compartments, including the cell membrane and the cytoplasm. Cys-rich effector proteins form disulfide bridges, which are thought to be important for maintenance of the protein structure and function and to enhance stability in the host apoplast. Therefore, finding a large content of this class of effector proteins in the genomes of the poplar rust fungi and powdery mildew fungi is not surprising (Duplessis et al. 2011; Hacquard et al. 2011; Kamoun 2006; Spanu et al. 2010; Stergiopoulos and de Wit 2009). The persistence of the histidine- and alanine-rich proteins in patients with successfully treated $P$. falciparum malaria indicates that HRPII are also very stable proteins with a long half-life in vivo (Mayxay et al. 2001). The function of histidine- and alanine-rich proteins in plant-colonizing fungi is unknown but it is tempting to speculate that the highly conserved position of histidine residues in Piriformospora indica DELD proteins might play an important role in correct folding of the proteins and stability in the apoplast and, most probably, make these proteins sensitive to changes in $\mathrm{pH}$. Although $P$. indica possesses a low number of transposable elements, the occurrence of the DELD proteins in the genome correlated with their presence (Zuccaro et al. 2011). This is similar to effectors 
found in other filamentous organisms (Raffaele et al. 2010; Sacristan et al. 2009; Schornack et al. 2010; Spanu et al. 2010), where the association of effectors to retrotransposons could have provided an effective way for their expansion and consequent diversification (Koeck et al. 2011). In contrast to the maize biotrophic pathogens $U$. maydis and the related fungus Sporisorium reilianum, but similar to the candidate secreted effector proteins identified in the Blumeria graminis $\mathrm{f}$. $\mathrm{sp}$. hordei genome (Schirawski et al. 2010; Spanu et al. 2010), the DELD proteins showed no obvious clustering in the genome. The increasing information available from recent genome and transcriptome analyses of symbiotic as well as pathogenic fungi enabled the identification of a plethora of effector candidates (Stergiopoulos and de Wit 2009). Functional characterization is now required in order to understand the role played by these effector proteins during symbiosis.

\section{Hide and seek between host and microbe.}

The cell walls of organisms from different taxonomic kingdoms are typically chemically and structurally very different from each other. Therefore, the perception of microbial cell wall components by their respective hosts is an effective strategy to seek for potential threads. Because modification of the main components of a cell wall is not possible without significant loss of viability, microbes have evolved different strategies, such as cell wall masking, in order to hide themselves from their hosts. Recent findings show that lectins and lectin-like proteins play an important role in this hide and seek between host and microbe (de Jonge et al. 2010; Marshall et al. 2011). Lectins are a ubiquitous group of proteins occurring in all domains of life. They are of non-immuno origin and have the ability to bind, often with a high specificity, to different types of carbohydrates (Gabius et al. 2002; Goldstein et al. 1980). The carbohydrates can be structurally organized, as in the cell wall of fungi or plants (e.g., cellulose or chitin), or modify the surface of proteins by, for example, $\mathrm{N}$ - or O-glycosylation (Alexandre et al. 2010; Chrispeels and Raikhel 1991; Jones and Ospina-Giraldo 2011). The host uses lectins to identify potential microbial threads by specifically binding to either major cell wall components that are commonly released during microbe-host interaction or modifications of the microbe's cell wall (de Jonge et al. 2010; Esteban et al. 2011; Jones and Ospina-Giraldo 2011). On the other side, the microbe uses lectins to either protect its cell wall from host enzymatic attack or sequester free oligosaccharides released from the cell wall. By doing so, the microbe hides its cell wall components from being detected by the host immune system (de Jonge et al. 2010). The microbe's advantage in using lectins rather than modifying the cell wall relies on the fact that these small proteins can be produced quickly and specifically at the time and place where they are needed. Interestingly, comparative genomics revealed a significant expansion of proteins containing either one or a combination of the carbohydrate-binding domains lysin motif (LysM), cell wall integrity and stress response component (WSC) or carbohydrate-binding module family 1 (CBM_1) in the genome of $P$. indica (Zuccaro et al. 2011). This significant expansion of carbohydrate-binding proteins is not observed in any other fungal genome that has been sequenced thus far (Fig. 4C). Phylogenetic analysis of the LysM domains revealed that the majority of LysM proteins cluster in a $P$. indica-specific clade, suggesting a strong and recent expansion (Zuccaro et al. 2011). Current reports have pointed out the importance of LysM-containing proteins in plant-fungus interactions (de Jonge et al. 2010; Marshall et al. 2011). In Cladosporium fulvum, the LysM domain-containing protein Avr4 was shown to be able to bind to the fungal cell wall, thereby protecting it from the activity of plant-secreted chiti- nases. A second effector protein (Ecp6) from C. fulvum which possesses three of these domains can sequester chitin fragments from the apoplast competing with the plant LysM domaincontaining chitin receptors (de Jonge et al. 2010; Kaku et al. 2006; Miya et al. 2007; van den Burg et al. 2006). Similar results were reported from experiments performed with two proteins from $M$. graminicola: Mg3LysM, with three LysM domains, and Mg1LysM, with one LysM domain, whereby Mg3LysM was shown to function in both chitin shielding and sequestration (Marshall et al. 2011). Thus far, we can only speculate on the function of lectin-like proteins in $P$. indica, because functional data is missing. From the present knowledge, it could be assumed that fungal-secreted lectins containing three LysM domains (such as Ecp6 or Mg3LysM) are involved in chitin sequestration whereas, for chitin shielding, one domain may be sufficient. Two of the putative secreted lectin-like LysM proteins in $P$. indica have one LysM domain and one of them is induced during the colonization of barley roots resembling Avr4 or Mg1LysM (Zuccaro et al. 2011). The other LysM-containing lectins in $P$. indica possess four to six LysM domains. Their function in symbiosis, if any, deserves further analysis.

Even more astonishing is the expansion of putative glucanbinding WSC proteins in $P$. indica. With 36 members, this is the largest expansion of WSC-containing proteins in fungal genomes to date (Fig. 4C). Most of them are devoid of other conserved domains and resemble lectins (Zuccaro et al. 2011). Very little information is available about lectins that bind $\beta$ glucans in fungi. The Saccharomyces cervisiae protein Wsc1, which binds $\beta$-glucan via its WSC domain, has been shown to be localized in the cell membrane, where it acts as sensor of cell wall integrity and alkaline $\mathrm{pH}$ stress (Heinisch et al. 2010; Serrano et al. 2006). A similar function has been reported for two WSC proteins (wscA and wscB) from Aspergillus nidulans (Futagami et al. 2011). These proteins seem to be sensors of osmotic and acidic $\mathrm{pH}$ stresses, thereby regulating the synthesis of $\alpha-1,3$-glucan based on the different environmental stresses. However, it seems unlikely that, just because of the high number of WSC proteins in $P$. indica, all of them have a function in cell wall stress signaling. Recently, it was shown in mammals that glucan-binding receptors such as dectin- 1 are involved in the recognition of fungal threads (Esteban et al. 2011). Therefore, it could be that some of the WSC-containing proteins might function in sensing the presence of other fungi. Taking into account what is known about the LysM proteins and the fact that some of the $P$. indica WSC lectins are induced in planta, it is also possible that these have a function in hiding $\beta$-glucans in the fungal cell wall from being hydrolyzed by the plant glucanases or by sequestering glucan fragments that are released during the penetration of the host cell.

In addition to the lectin-like proteins that putatively bind to fungal cell wall components, an expansion for proteins containing the cellulose-binding domain CBM_1 was identified in the genome of $P$. indica. The symbiotic fungus contains several of the "classical" hydrolytic proteins that combine the CBM_1 domain with a catalytic enzyme domain (Zuccaro et al. 2011). In addition to these classical hydrolytic enzymes, there are 14 proteins that have a lectin-like structure with one or two CBM_1 domains. Colonization of barley is accompanied by induction of these lectins in the early phase (Zuccaro et al. 2011). CBM_1-containing proteins such as swollen in from Trichoderma reesei and cellulose-binding elicitor lectin from Phytophthora infestans have been reported to possess an expansin-like function on cellulose-containing cell walls (Gaulin et al. 2006; Jones and Ospina-Giraldo 2011; Saloheimo et al. 2002). These findings support the hypothesis that cellulose binding lectins from $P$. indica might facilitate colonization by 
increasing permeability of the host cell wall at the penetration site. This strategy would avoid the excessive use of cell wall hydrolytic enzymes which could activate plant defense. Altogether, it seems that Piriformospora indica has evolved different universally acting hide and seek strategies that allow the fungus to interact with the environment.

\section{Conclusions and perspectives.}

Access to the manually annotated genome sequence provides unprecedented insights into how $P$. indica penetrates and establishes itself within its hosts. Together with the analysis of the plant responses, distinctive features of $P$. indica root colonization were uncovered. These include the effective capability to suppress $\mathrm{H}_{2} \mathrm{O}_{2}$ accumulation and host immune responses triggered by various MAMPs in roots, expression of fungal lectin and DELD proteins during biotrophy, and modification of several host key processes such as lipid and phytohormone signaling, cell death, and defense responses (Figs. 1 and 3). The genome draft is expected to serve as a framework for the identification of specific $P$. indica genes involved in biotrophy and in the switch to cell death. A systematic gene knockdown strategy will now permit insights into all aspects and steps of endophytic development, including functional characterization of specific CWDE and secreted effector molecules. With respect to the effectors of $P$. indica, one of the challenges will be to determine whether their activity resides in the apoplast or inside the host cells and which processes they control. In the frame of the JGI Community Sequencing Program (ID 305) "Exploring the Genome Diversity of Mycorrhizal Fungi", the genome and transcriptome of the sebacinoid fungus Sebacina vermifera (orchid mycorrhiza), a fungus closely related to $P$. indica, is in the process of being sequenced. Availability of the transcriptome and genome data for this isolate will aid in the identification of the symbiosis determinants and their evolution by genome comparison and polymorphism of symbiosis regulated genes.

\section{NOTE ADDED IN PROOF}

Since the completion of this manuscript, a review has been published by Qiang and associates (2011) that nicely complements ours and is relevant to this topic.

\section{ACKNOWLEDGMENTS}

We apologize to those whose original work could not be cited in this review because of space limitations. We thank S. Pfiffi and C. Grimm (Max Planck Institute, Marburg) for the confocal microscopic pictures and the IMPRS (International Max Planck Research Schools) for funding.

\section{LITERATURE CITED}

Alexandre, K. B., Gray, E. S., Lambson, B. E., Moore, P. L., Choge, I. A., Mlisana, K., Karim, S. S., McMahon, J., O'Keefe, B., Chikwamba, R., and Morris, L. 2010. Mannose-rich glycosylation patterns on HIV-1 subtype C gp120 and sensitivity to the lectins, Griffithsin, Cyanovirin-N and Scytovirin. Virology 402:187-196.

Anthony, R. G., Henriques, R., Helfer, A., Meszaros, T., Rios, G., Testerink, C., Munnik, T., Deak, M., Koncz, C., and Bogre, L. 2004. A protein kinase target of a PDK1 signalling pathway is involved in root hair growth in Arabidopsis. EMBO (Eur. Mol. Biol. Organ.) J. 23:572-581.

Anthony, R. G., Khan, S., Costa, J., Pais, M. S., and Bogre, L. 2006. The Arabidopsis protein kinase PTI1-2 is activated by convergent phosphatidic acid and oxidative stress signaling pathways downstream of PDK1 and OXI1. J. Biol. Chem. 281:37536-37546.

Baltruschat, H., Fodor, J., Harrach, B. D., Niemczyk, E., Barna, B., Gullner, G., Janeczko, A., Kogel, K. H., Schäfer, P., Schwarczinger, I., Zuccaro, A., and Skoczowski, A. 2008. Salt tolerance of barley induced by the root endophyte Piriformospora indica is associated with a strong increase in antioxidants. New Phytol. 180:501-510.

Basiewicz, M., Weiß, M., Kogel, K. H., Langen, G., Zorn, H., and Zuccaro, A. 2011. Molecular and phenotypic characterization of Sebacina ver- mifera strains associated with orchids, and the description of Piriformospora williamsii sp. nov. Fungal Biol. Online publication. doi:10.1016/j.funbio.2011.11.003

Bidartondo, M. I., Bruns, T. D., Weiss, M., Sergio, C., and Read, D. J. 2003. Specialized cheating of the ectomycorrhizal symbiosis by an epiparasitic liverwort. Proc. Biol. Sci. 270:835-842.

Boller, T. 1995. Chemoperception of microbial signals in plant cells. Annu. Rev. Plant Physiol. 46:189-214.

Boller, T., and Felix, G. 2009. A renaissance of elicitors: Perception of microbe-associated molecular patterns and danger signals by patternrecognition receptors. Annu. Rev. Plant Biol. 60:379-406.

Brefort, T., Doehlemann, G., Mendoza-Mendoza, A., Reissmann, S., Djamei, A., and Kahmann, R. 2009. Ustilago maydis as a Pathogen. Annu. Rev. Phytopathol. 47:423-445.

Brundrett, M. C. 2006. Understanding the roles of multifunctional mycorrhizal and endophytic fungi. Pages 281-298 in: Microbial Root Endophytes. B. Schulz, C. Boyle, and T. N. Sieber, eds. Springer Verlag, Berlin.

Burmester, A., Shelest, E., Glockner, G., Heddergott, C., Schindler, S., Staib, P., Heidel, A., Felder, M., Petzold, A., Szafranski, K., Feuermann, M., Pedruzzi, I., Priebe, S., Groth, M., Winkler, R., Li, W. J., Kniemeyer, O., Schroeckh, V., Hertweck, C., Hube, B., White, T. C., Platzer, M., Guthke, R., Heitman, J., Wostemeyer, J., Zipfel, P. F., Monod, M., and Brakhage, A. A. 2011. Comparative and functional genomics provide insights into the pathogenicity of dermatophytic fungi. Genome Biol. 12:R7. Published online.

Camehl, I., and Oelmüller, R. 2010. Do ethylene response factors-9 and -14 repress PR gene expression in the interaction between Piriformospora indica and Arabidopsis? Plant Signal. Behav. 5:932-936.

Camehl, I., Sherameti, I., Venus, Y., Bethke, G., Varma, A., Lee, J., and Oelmüller, R. 2010. Ethylene signalling and ethylene-targeted transcription factors are required to balance beneficial and nonbeneficial traits in the symbiosis between the endophytic fungus Piriformospora indica and Arabidopsis thaliana. New Phytol. 185:1062-1073.

Camehl, I., Drzewiecki, C., Vadassery, J., Shahollari, B., Sherameti, I., Forzani, C., Munnik, T., Hirt, H., and Oelmüller, R. 2011. The OXI1 kinase pathway mediates Piriformospora indica-induced growth promotion in Arabidopsis. PLoS Pathog. 7:e1002051. Published online.

Chrispeels, M. J., and Raikhel, N. V. 1991. Lectins, lectin genes, and their role in plant defense. Plant Cell 3:1-9.

Clark, T. A., and Anderson, J. B. 2004. Dikaryons of the basidiomycete fungus Schizophyllum commune: Evolution in long-term culture. Genetics 167:1663-1675.

de Jong, C. F., Laxalt, A. M., Bargmann, B. O. R., de Wit, P. J. G. M., Joosten, M. H. A. J., and Munnik, T. 2004. Phosphatidic acid accumulation is an early response in the Cf-4/Avr4 interaction. Plant J. 39:1-12.

de Jonge, R., van Esse, H. P., Kombrink, A., Shinya, T., Desaki, Y., Bours, R., van der Krol, S., Shibuya, N., Joosten, M. H., and Thomma, B. P. 2010. Conserved fungal LysM effector Ecp6 prevents chitin-triggered immunity in plants. Science 329:953-955.

Depuydt, S., and Hardtke, C. S. 2011. Hormone signalling crosstalk in plant growth regulation. Curr. Biol. 21:R365-373.

Deshmukh, S., Huckelhoven, R., Schäfer, P., Imani, J., Sharma, M., Weiss, M., Waller, F., and Kogel, K. H. 2006. The root endophytic fungus Piriformospora indica requires host cell death for proliferation during mutualistic symbiosis with barley. Proc. Natl. Acad. Sci. U.S.A. 103:18450-18457.

de Torres-Zabala, M., Truman, W., Bennett, M. H., Lafforgue, G., Mansfield, J.W., Rodriguez Egea, P., Bogre, L., and Grant, M. 2007. Pseudomonas syringae pv. tomato hijacks the Arabidopsis abscisic acid signalling pathway to cause disease. EMBO (Eur. Mol. Biol. Organ.) J. 26:1434-1443.

Devarenne, T. P., Ekengren, S. K., Pedley, K. F., and Martin, G. B. 2006. Adi3 is a Pdk1-interacting AGC kinase that negatively regulates plant cell death. EMBO (Eur. Mol. Biol. Organ.) J. 25:255-265.

Duplessis, S., Cuomo, C. A., Lin, Y. C., Aerts, A., Tisserant, E., VeneaultFourrey, C., Joly, D. L., Hacquard, S., Amselem, J., Cantarel, B. L., Chiu, R., Coutinho, P. M., Feau, N., Field, M., Frey, P., Gelhaye, E., Goldberg, J., Grabherr, M. G., Kodira, C. D., Kohler, A., Kues, U., Lindquist, E. A., Lucas, S. M., Mago, R., Mauceli, E., Morin, E., Murat, C., Pangilinan, J. L., Park, R., Pearson, M., Quesneville, H., Rouhier, N., Sakthikumar, S., Salamov, A. A., Schmutz, J., Selles, B., Shapiro, H., Tanguay, P., Tuskan, G. A., Henrissat, B., Van de Peer, Y., Rouze, P. Ellis, J. G., Dodds, P. N., Schein, J. E., Zhong, S., Hamelin, R. C., Grigoriev, I. V., Szabo, L. J., and Martin, F. 2011. Obligate biotrophy features unraveled by the genomic analysis of rust fungi. Proc. Natl. Acad. Sci. U.S.A. 108:9166-9171.

Eastwood, D. C., Floudas, D., Binder, M., Majcherczyk, A., Schneider, P., Aerts, A., Asiegbu, F. O., Baker, S. E., Barry, K., Bendiksby, M., Blumentritt, M., Coutinho, P. M., Cullen, D., de Vries, R. P., Gathman, 
A., Goodell, B., Henrissat, B., Ihrmark, K., Kauserud, H., Kohler, A. LaButti, K., Lapidus, A., Lavin, J. L., Lee, Y. H., Lindquist, E., Lilly, W., Lucas, S., Morin, E., Murat, C., Oguiza, J. A., Park, J., Pisabarro, A. G., Riley, R., Rosling, A., Salamov, A., Schmidt, O., Schmutz, J., Skrede, I., Stenlid, J., Wiebenga, A., Xie, X., Kues, U., Hibbett, D. S., Hoffmeister, D., Hogberg, N., Martin, F., Grigoriev, I. V., and Watkinson, S. C. 2011. The plant cell wall-decomposing machinery underlies the functional diversity of forest fungi. Science 333:762-765.

Ek-Ramos, M. J., Avila, J., Cheng, C., Martin, G. B., and Devarenne, T. P. 2010. The T-loop extension of the tomato protein kinase AvrPto-dependent Pto-interacting protein 3 (Adi3) directs nuclear localization for suppression of plant cell death. J. Biol. Chem. 285:17584-17594.

Esteban, A., Popp, M. W., Vyas, V. K., Strijbis, K., Ploegh, H. L., and Fink, G. R. 2011. Fungal recognition is mediated by the association of dectin-1 and galectin-3 in macrophages. Proc. Natl. Acad. Sci. U.S.A. 108:14270-14275.

Fakhro, A., Andrade-Linares, D.R., von Bargen, S., Bandte, M., Buttner, C., Grosch, R., Schwarz, D., and Franken, P. 2010. Impact of Piriformospora indica on tomato growth and on interaction with fungal and viral pathogens. Mycorrhiza 20:191-200.

Furman-Matarasso, N., Cohen, E., Du, Q., Chejanovsky, N., Hanania, U., and Avni, A. 1999. A point mutation in the ethylene-inducing xylanase elicitor inhibits the beta-1-4-endoxylanase activity but not the elicitation activity. Plant Physiol. 121:345-351.

Futagami, T., Nakao, S., Kido, Y., Oka, T., Kajiwara, Y., Takashita, H., Omori, T., Furukawa, K., and Goto, M. 2011. Putative stress sensors $\mathrm{WscA}$ and WscB are involved in hypo-osmotic and acidic $\mathrm{pH}$ stress tolerance in Aspergillus nidulans. Eukaryot. Cell 10:1504-1515.

Gabius, H.J., André, S., Kaltner, H., Siebert, H. C. 2002. The sugar code: functional lectinomics. Biochim. Biophys. Acta. 1572:165-177.

Garcia-Garrido, J. M., and Ocampo, J. A. 2002. Regulation of the plant defence response in arbuscular mycorrhizal symbiosis. J. Exp. Bot. 53:1377-1386.

Gaulin, E., Drame, N., Lafitte, C., Torto-Alalibo, T., Martinez, Y., AmelineTorregrosa, C., Khatib, M., Mazarguil, H., Villalba-Mateos, F., Kamoun, S., Mazars, C., Dumas, B., Bottin, A., Esquerre-Tugaye, M. T., and Rickauer, M. 2006. Cellulose binding domains of a Phytophthora cell wall protein are novel pathogen-associated molecular patterns. Plant Cell 18:1766-1777.

Gladfelter, A., and Berman, J. 2009. Dancing genomes: Fungal nuclear positioning. Nat. Rev. Microbiol. 7:875-886.

Godfrey, D., Bohlenius, H., Pedersen, C., Zhang, Z., Emmersen, J., and Thordal-Christensen, H. 2010. Powdery mildew fungal effector candidates share N-terminal Y/F/WxC-motif. BMC Genomics 11:317.

Goldstein, I. J., Hughes, R. C., Monsigny, M., Osawa, T., and Sharon, N. 1980. What should be called a lectin? Nature 285:66.

Goodwin, S. B., M'Barek S. B., Dhillon, B., Wittenberg, A. H., Crane, C. F., Hane, J. K., Foster, A. J., Van der Lee, T. A., Grimwood, J., Aerts, A., Antoniw, J., Bailey, A., Bluhm, B., Bowler, J., Bristow, J., van der Burgt, A., Canto-Canche, B., Churchill, A. C., Conde-Ferraez, L., Cools, H. J., Coutinho, P. M., Csukai, M., Dehal, P., De Wit, P., Donzelli, B., van de Geest, H. C., van Ham, R. C., Hammond-Kosack, K. E., Henrissat, B., Kilian, A., Kobayashi, A. K., Koopmann, E., Kourmpetis, Y., Kuzniar, A., Lindquist, E., Lombard, V., Maliepaard, C., Martins, N., Mehrabi, R., Nap, J. P., Ponomarenko, A., Rudd, J. J., Salamov, A., Schmutz, J., Schouten, H. J., Shapiro, H., Stergiopoulos, I., Torriani, S. F., Tu, H., de Vries, R. P., Waalwijk, C., Ware, S. B., Wiebenga, A., Zwiers, L. H., Oliver, R. P., Grigoriev, I. V., and Kema, G. H. 2011. Finished genome of the fungal wheat pathogen Mycosphaerella graminicola reveals dispensome structure, chromosome plasticity, and stealth pathogenesis. PLoS Genet. 7:e1002070. Published online.

Hacquard, S. P., Joly, D. L., Lin, Y. C., Tisserant, E., Feau, N., Delaruelle, C., Legue, V., Kohler, A., Tanguay, P., Petre, B., Frey, P., Van de Peer, Y., Rouz, P., Martin, F. M., Hamelin, R. C., and Duplessis, S. B. 2012. A comprehensive analysis of genes encoding small secreted proteins identifies candidate effectors in Melampsora larici-populina (poplar leaf rust). Mol. Plant-Microbe Interact. 3:279-293.

Hann, D. R., Gimenez-Ibanez, S., and Rathjen, J. P. 2010. Bacterial virulence effectors and their activities. Curr. Opin. Plant Biol. 13:388-393.

Heinisch, J. J., Dupres, V., Wilk, S., Jendretzki, A., and Dufrene, Y. F. 2010. Single-molecule atomic force microscopy reveals clustering of the yeast plasma-membrane sensor Wsc1. PLoS One 5:e11104. Published online.

Hibbett, D. S., and Matheny, P. B. 2009. The relative ages of ectomycorrhizal mushrooms and their plant hosts estimated using Bayesian relaxed molecular clock analyses. BMC Biol. 7:13.

Hirt, H., Garcia, A. V., and Oelmüller, R. 2011. AGC kinases in plant development and defense. Plant Signal. Behav. 6:1030-1033.

Iwasa, M., S. Tanabe, and T. Kamada. 1998. The two nuclei in the dikaryon of the homobasidiomycete Coprinus cinereus change position after each conjugate division. Fungal Genet. Biol. 23:110-116.

Jacobs, S., Zechmann, B., Molitor, A., Trujillo, M., Petutschnig, E., Lipka, V., Kogel, K. H., and Schäfer, P. 2011. Broad-spectrum suppression of innate immunity is required for colonization of Arabidopsis roots by the fungus Piriformospora indica. Plant Physiol. 156:726-740.

James, T. Y., Stenlid, J., Olson, A., and Johannesson, H. 2008. Evolutionary significance of imbalanced nuclear ratios within heterokaryons of the basidiomycete fungus Heterobasidion parviporum. Evolution 62:2279-2296.

Jones, R. W., and Ospina-Giraldo, M. 2011. Novel cellulose-binding-domain protein in Phytophthora is cell wall localized. PLoS One 6:e23555. Published online.

Joneson, S., Stajich, J. E., Shiu, S. H., and Rosenblum, E. B. 2011. Genomic transition to pathogenicity in chytrid Fungi. PLoS Pathog. 7:e1002338. doi:10.1371/journal.ppat.1002338. Online publication.

Kaku, H., Nishizawa, Y., Ishii-Minami, N., Akimoto-Tomiyama, C., Dohmae, N., Takio, K., Minami, E., and Shibuya, N. 2006. Plant cells recognize chitin fragments for defense signaling through a plasma membrane receptor. Proc. Natl. Acad. Sci. U.S.A. 103:11086-11091.

Kamoun, S. 2006. A catalogue of the effector secretome of plant pathogenic oomycetes. Annu. Rev. Phytopathol. 44:41-60.

Kloppholz, S., Kuhn, H., and Requena, N. 2011. A secreted fungal effector of Glomus intraradices promotes symbiotic biotrophy. Curr. Biol. 21:1204-1209.

Koeck, M., Hardham, A. R., and Dodds, P. N. 2011. The role of effectors of biotrophic and hemibiotrophic fungi in infection. Cell Microbiol. 13:1849-1857.

Laxalt, A. M., ter Riet, B., Verdonk, J. C., Parigi, L., Tameling, W. I., Vossen, J., Haring, M., Musgrave, A., and Munnik, T. 2001. Characterization of five tomato phospholipase D cDNAs: Rapid and specific expression of LePLDbeta1 on elicitation with xylanase. Plant J. 26:237247.

Lee, Y. C., Johnson, J. M., Chien, C. T., Sun, C., Cai, D., Lou, B., Oelmüller, R., and Yeh, K. W. 2011. Growth promotion of Chinese cabbage and Arabidopsis by Piriformospora indica is not stimulated by mycelium-synthesized auxin. Mol. Plant-Microbe Interact. 24:421-431.

Lilly, W. W., Stajich, J. E., Pukkila, P. J., Wilke, S. K., Inoguchi, N., and Gathman, A. C. 2008. An expanded family of fungalysin extracellular metallopeptidases of Coprinopsis cinerea. Mycol. Res. 112:389-398.

Marshall, R., Kombrink, A., Motteram, J., Loza-Reyes, E., Lucas, J., Hammond-Kosack, K. E., Thomma, B. P., and Rudd, J. J. 2011. Analysis of two in planta expressed LysM effector homologs from the fungus Mycosphaerella graminicola reveals novel functional properties and varying contributions to virulence on wheat. Plant Physiol. 156:756769.

Matheny, P. B., Wang, Z., Binder, M., Curtis, J. M., Lim, Y. W., Nilsson, R. H., Hughes, K. W., Hofstetter, V., Ammirati, J. F., Schoch, C. L., Langer, E., Langer, G., McLaughlin, D. J., Wilson, A. W., Froslev, T., Ge, Z. W., Kerrigan, R. W., Slot, J. C., Yang, Z. L., Baroni, T. J., Fischer, M., Hosaka, K., Matsuura, K., Seidl, M. T., Vauras, J., and Hibbett, D. S. 2007. Contributions of rpb2 and tef1 to the phylogeny of mushrooms and allies (Basidiomycota, Fungi). Mol. Phylogenet. Evol. 43:430-451.

Mayxay, M., Pukrittayakamee, S., Chotivanich, K., Looareesuwan, S., and White, N. J. 2001. Persistence of Plasmodium falciparum HRP-2 in successfully treated acute falciparum malaria. Trans. R. Soc. Trop. Med. Hyg. 95:179-182.

Miya, A., Albert, P., Shinya, T., Desaki, Y., Ichimura, K., Shirasu, K., Narusaka, Y., Kawakami, N., Kaku, H., and Shibuya, N. 2007. CERK1, a LysM receptor kinase, is essential for chitin elicitor signaling in Arabidopsis. Proc. Natl. Acad. Sci. U.S.A. 104:19613-19618.

Molitor, A., and Kogel, K. H. 2009. Induced resistance triggered by Piriformospora indica. Plant Signal. Behav. 4:215-216.

Pieterse, C. M., Leon-Reyes, A., Van der Ent, S., and Van Wees, S. C. 2009. Networking by small-molecule hormones in plant immunity. Nat. Chem. Biol. 5:308-316.

Plett, J. M., and Martin, F. 2011. Blurred boundaries: Lifestyle lessons from ectomycorrhizal fungal genomes. Trends Genet. 27:14-22.

Qiang, S., Weiss, M., Kogel, K. H., and Schäfer, P. 2011. Piriformospora indica-A mutualistic basidiomycete with an exceptionally large plant host range. Mol. Plant Pathol. Published online.

Raffaele, S., Win, J., Cano, L. M., and Kamoun, S. 2010. Analyses of genome architecture and gene expression reveal novel candidate virulence factors in the secretome of Phytophthora infestans. BMC Genomics 11.

Raper, C. A., Raper, J. R., and Miller, R. E. 1972. Genetic analysis of life cycle of Agaricus bisporus. Mycologia 64:1088-1117.

Rentel, M. C., Lecourieux, D., Ouaked, F., Usher, S. L., Petersen, L., Okamoto, H., Knight, H., Peck, S. C., Grierson, C. S., Hirt, H., and Knight, M. R. 2004. OXI1 kinase is necessary for oxidative burst-mediated signalling in Arabidopsis. Nature 427:858-861. 
Robert-Seilaniantz, A., Grant, M., and Jones, J. D. 2011. Hormone crosstalk in plant disease and defense: More than just jasmonate-salicylate antagonism. Annu. Rev. Phytopathol. 49:317-343.

Rodriguez, R., and Redman, R. 2008. More than 400 million years of evolution and some plants still can't make it on their own: Plant stress tolerance via fungal symbiosis. J. Exp. Bot. 59:1109-1114.

Rodriguez, R. J., White, J. F., Jr., Arnold, A. E., and Redman, R. S. 2009. Fungal endophytes: Diversity and functional roles. New Phytol. 182:314330.

Rosling, A., Cox, F., Cruz-Martinez, K., Ihrmark, K., Grelet, G. A., Lindahl, B. D., Menkis, A., and James, T. Y. 2011. Archaeorhizomycetes: Unearthing an ancient class of ubiquitous soil fungi. Science 333:876-879.

Rotblat, B., Enshell-Seijffers, D., Gershoni, J. M., Schuster, S., and Avni, A. 2002. Identification of an essential component of the elicitation active site of the EIX protein elicitor. Plant J. 32:1049-1055.

Sacristan, S., Vigouroux, M., Pedersen, C., Skamnioti, P., ThordalChristensen, H., Micali, C., Brown, J. K. M., and Ridout, C. J. 2009. Coevolution between a family of parasite virulence effectors and a class of LINE-1 retrotransposons. PLoS One 4:e7463. Published online.

Saloheimo, M., Paloheimo, M., Hakola, S., Pere, J., Swanson, B., Nyyssonen, E., Bhatia, A., Ward, M., and Penttila, M. 2002. Swollenin, a Trichoderma reesei protein with sequence similarity to the plant expansins, exhibits disruption activity on cellulosic materials. Eur. J. Biochem. 269:4202-4211.

Schäfer, P., Pfiffi, S., Voll, L. M., Zajic, D., Chandler, P. M., Waller, F. Scholz, U., Pons-Kuhnemann, J., Sonnewald, S., Sonnewald, U., and Kogel, K. H. 2009. Manipulation of plant innate immunity and gibberellin as factor of compatibility in the mutualistic association of barley roots with Piriformospora indica. Plant J. 59:461-474.

Schirawski, J., Mannhaupt, G., Munch, K., Brefort, T., Schipper, K., Doehlemann, G., Di Stasio, M., Rossel, N., Mendoza-Mendoza, A. Pester, D., Muller, O., Winterberg, B., Meyer, E., Ghareeb, H., Wollenberg, T., Munsterkotter, M., Wong, P., Walter, M., Stukenbrock, E., Guldener, U., and Kahmann, R. 2010. Pathogenicity determinants in smut fungi revealed by genome comparison. Science 330:1546-1548.

Schornack, S., van Damme, M., Bozkurt, T. O., Cano, L. M., Smoker, M. Thines, M., Gaulin, E., Kamoun, S., and Huitema, E. 2010. Ancient class of translocated oomycete effectors targets the host nucleus. Proc. Natl. Acad. Sci. U.S.A. 107:17421-17426.

Schulz, B. 2006. Mutualistic interactions with fungal root endophytes Pages 261-279 in: Microbial Root Endophytes. B. Schulz, C. Boyle, and T. N. Sieber, eds. Springer Verlag, Berlin.

Schulz, B., and Boyle, C. 2005. The endophytic continuum. Mycol. Res. 109:661-686.

Schuurs, T. A., Dalstra, H. J., Scheer, J. M., and Wessels, J. G. 1998. Positioning of nuclei in the secondary mycelium of Schizophyllum commune in relation to differential gene expression. Fungal Genet. Biol. 23:150-161.

Serrano, R., Martin, H., Casamayor, A., and Arino, J. 2006. Signaling alkaline $\mathrm{pH}$ stress in the yeast Saccharomyces cerevisiae through the Wsc1 cell surface sensor and the Slt2 MAPK pathway. J. Biol. Chem. 281:39785-39795.

Sherameti, I., Shahollari, B., Venus, Y., Altschmied, L., Varma, A., and Oelmüller, R. 2005. The endophytic fungus Piriformospora indica stimulates the expression of nitrate reductase and the starch-degrading enzyme glucan-water dikinase in tobacco and Arabidopsis roots through a homeodomain transcription factor that binds to a conserved motif in their promoters. J. Biol. Chem. 280:26241-26247.

Sherameti, I., Tripathi, S., Varma, A., and Oelmüller, R. 2008. The rootcolonizing endophyte Piriformospora indica confers drought tolerance in Arabidopsis by stimulating the expression of drought stress-related genes in leaves. Mol. Plant-Microbe Interact. 21:799-807.

Sirrenberg, A., Gobel, C., Grond, S., Czempinski, N., Ratzinger, A., Karlovsky, P., Santos, P., Feussner, I., and Pawlowski, K. 2007. Piriformospora indica affects plant growth by auxin production. Physiol. Plant. 131:581-589.

Spanu, P. D., Abbott, J. C., Amselem, J., Burgis, T. A., Soanes, D. M., Stuber, K., Ver Loren van Themaat, E., Brown, J. K., Butcher, S. A., Gurr, S. J., Lebrun, M. H., Ridout, C. J., Schulze-Lefert, P., Talbot, N. J., Ahmadinejad, N., Ametz, C., Barton, G. R., Benjdia, M., Bidzinski, P., Bindschedler, L. V., Both, M., Brewer, M. T., Cadle-Davidson, L., Cadle-Davidson, M. M., Collemare, J., Cramer, R., Frenkel, O., Godfrey, D., Harriman, J., Hoede, C., King, B. C., Klages, S., Kleemann, J., Knoll, D., Koti, P. S., Kreplak, J., Lopez-Ruiz, F. J., Lu, X., Maekawa, T., Mahanil, S., Micali, C., Milgroom, M. G., Montana, G., Noir, S., O’Connell, R. J., Oberhaensli, S., Parlange, F., Pedersen, C., Quesneville, H., Reinhardt, R., Rott, M., Sacristan, S., Schmidt, S. M., Schon, M., Skamnioti, P., Sommer, H., Stephens, A., Takahara, H., Thordal-Christensen, H., Vigouroux, M., Wessling, R., Wicker, T., and Panstruga, R. 2010. Genome expansion and gene loss in powdery mil- dew fungi reveal tradeoffs in extreme parasitism. Science 330:1543 1546

Stajich, J. E., Wilke, S. K., Ahren, D., Au, C. H., Birren, B. W., Borodovsky, M., Burns, C., Canback, B., Casselton, L. A., Cheng, C. K., Deng, J. X., Dietrich, F. S., Fargo, D. C., Farman, M. L., Gathman, A. C., Goldberg, J., Guigo, R., Hoegger, P. J., Hooker, J. B., Huggins, A., James, T. Y., Kamada, T., Kilaru, S., Kodira, C., Kues, U., Kupfert, D., Kwan, H. S., Lomsadze, A., Li, W. X., Lilly, W. W., Ma, L. J., Mackey, A. J., Manning, G., Martin, F., Muraguchi, H., Natvig, D. O., Palmerini, H., Ramesh, M. A., Rehmeyer, C. J., Roe, B. A., Shenoy, N., Stanke, M., Ter-Hovhannisyan, V., Tunlid, A., Velagapudi, R., Vision, T. J., Zeng, Q. D., Zolan, M. E., and Pukkila, P. J. 2010. Insights into evolution of multicellular fungi from the assembled chromosomes of the mushroom Coprinopsis cinerea (Coprinus cinereus). Proc. Natl. Acad. Sci. U.S.A. 107:11889-11894.

Stein, E., Molitor, A., Kogel, K. H., and Waller, F. 2008. Systemic resistance in Arabidopsis conferred by the mycorrhizal fungus Piriformospora indica requires jasmonic acid signaling and the cytoplasmic function of NPR1. Plant Cell Physiol. 49:1747-1751.

Stergiopoulos, I., and de Wit, P. J. 2009. Fungal effector proteins. Annu. Rev. Phytopathol. 47:233-263.

Sun, C., Johnson, J. M., Cai, D., Sherameti, I., Oelmüller, R., and Lou, B. 2010. Piriformospora indica confers drought tolerance in Chinese cabbage leaves by stimulating antioxidant enzymes, the expression of drought-related genes and the plastid-localized CAS protein. J. Plant Physiol. 167:1009-1017.

Testerink, C., and Munnik, T. 2005. Phosphatidic acid: A multifunctional stress signaling lipid in plants. Trends Plant Sci. 10:368-375.

Tudzynski, B., and Sharon, A. 2002. Biosynthesis, biological role and application of fungal phytohormones. Pages 183-212 in: The Mycota. K. Esser and J. W. Bennett, eds. Springer, New York.

Vadassery, J., Ritter, C., Venus, Y., Camehl, I., Varma, A., Shahollari, B., Novak, O., Strnad, M., Ludwig-Muller, J., and Oelmüller, R. 2008. The role of auxins and cytokinins in the mutualistic interaction between Arabidopsis and Piriformospora indica. Mol. Plant-Microbe Interact. 21, 1371-1383.

Vadassery, J., Ranf, S., Drzewiecki, C., Mithofer, A., Mazars, C., Scheel, D., Lee, J., and Oelmüller, R. 2009. A cell wall extract from the endophytic fungus Piriformospora indica promotes growth of Arabidopsis seedlings and induces intracellular calcium elevation in roots. Plant $\mathrm{J}$. 59:193-206.

van den Burg, H. A., Harrison, S. J., Joosten, M. H., Vervoort, J., and de Wit, P. J. 2006. Cladosporium fulvum Avr4 protects fungal cell walls against hydrolysis by plant chitinases accumulating during infection. Mol. Plant-Microbe Interact. 19:1420-1430.

van der Luit, A. H., Piatti, T., van Doorn, A., Musgrave, A., Felix, G., Boller, T., and Munnik, T. 2000. Elicitation of suspension-cultured tomato cells triggers the formation of phosphatidic acid and diacylglycerol pyrophosphate. Plant Physiol. 123:1507-1516.

Verma, S., Varma, A., Rexer, K. H., Hassel, A., Kost, G., Sarbhoy, A., Bisen, P., Butehorn, B., and Franken, P. 1998. Piriformospora indica, gen. et sp. nov., a new root-colonizing fungus. Mycologia 90:896-903.

Wahl, R., Wippel, K., Goos, S., Kamper, J., and Sauer, N. 2010. A novel high-affinity sucrose transporter is required for virulence of the plant pathogen Ustilago maydis. PLoS Biol. 8:e1000303. Published online.

Waller, F., Achatz, B., Baltruschat, H., Fodor, J., Becker, K., Fischer, M., Heier, T., Huckelhoven, R., Neumann, C., von Wettstein, D., Franken, P., and Kogel, K. H. 2005. The endophytic fungus Piriformospora indica reprograms barley to salt-stress tolerance, disease resistance, and higher yield. Proc. Natl. Acad. Sci. U.S.A. 102:13386-13391.

Waller, F., Mukherjee, K., Deshmukh, S. D., Achatz, B., Sharma, M., Schäfer, P., and Kogel, K. H. 2008. Systemic and local modulation of plant responses by Piriformospora indica and related Sebacinales species. J. Plant Physiol. 165:60-70.

Wang, X. 2005. Regulatory functions of phospholipase D and phosphatidic acid in plant growth, development, and stress responses. Plant Physiol. 139:566-573.

Wang, X., Devaiah, S. P., Zhang, W., and Welti, R. 2006. Signaling functions of phosphatidic acid. Prog. Lipid Res. 45:250-278.

Warcup, J. H. 1988. Mycorrhizal associations of isolates of Sebacina vermifera. New Phytol. 110:227-231.

Warcup, J. H., and Talbot, P. H. B. 1966. Perfect states of some rhizoctonias. Br. Mycol. Soc. Trans. 49:427-435.

Warcup, J. H., and Talbot, P. H. B. 1967. Perfect states of rhizoctonias associated with orchids. New Phytol. 66:631-641.

Weiss, M., Selosse, M. A., Rexer, K. H., Urban, A., and Oberwinkler, F. 2004. Sebacinales: A hitherto overlooked cosm of heterobasidiomycetes with a broad mycorrhizal potential. Mycol. Res. 108:1003-1010.

Weiss, M., Sykorova, Z., Garnica, S., Riess, K., Martos, F., Krause, C., Oberwinkler, F., Bauer, R., and Redecker, D. 2011. Sebacinales every- 
where: Previously overlooked ubiquitous fungal endophytes. PLoS One 6:e16793. Published online.

Williams, P. G. 1985. Orchidaceous rhizoctonias in pot cultures of vesicular arbuscular mycorrhizal fungi. Can. J. Bot. 63:1329-1333.

Yadav, V., Kumar, M., Deep, D.K., Kumar, H., Sharma, R., Tripathi, T., Tuteja, N., Saxena, A. K., and Johri, A. K. 2010. A phosphate transporter from the root endophytic fungus Piriformospora indica plays a role in phosphate transport to the host plant. J. Biol. Chem. 285:2653226544.

Yamaguchi, T., Minami, E., Ueki, J., and Shibuya, N. 2005. Elicitor-induced activation of phospholipases plays an important role for the induction of defense responses in suspension-cultured rice cells. Plant Cell Physiol. 46:579-587.

Zegzouti, H., Anthony, R. G., Jahchan, N., Bogre, L., and Christensen, S. K. 2006. Phosphorylation and activation of PINOID by the phospholipid signaling kinase 3-phosphoinositide-dependent protein kinase 1 (PDK1) in Arabidopsis. Proc. Natl. Acad. Sci. U.S.A. 103:6404-6409.
Zipfel, C. 2009. Early molecular events in PAMP-triggered immunity. Curr Opin. Plant Biol. 12:414-420.

Zuccaro, A., Basiewicz, M., Zurawska, M., Biedenkopf, D., and Kogel, K. H. 2009. Karyotype analysis, genome organization, and stable genetic transformation of the root colonizing fungus Piriformospora indica. Fungal Genet. Biol. 46:543-550.

Zuccaro, A., Lahrmann, U., Guldener, U., Langen, G., Pfiffi, S., Biedenkopf, D., Wong, P., Samans, B., Grimm, C., Basiewicz, M., Murat, C., Martin, F., and Kogel, K. H. 2011. Endophytic life strategies decoded by genome and transcriptome analyses of the mutualistic root symbiont Piriformospora indica. PLoS Pathog. 7:e1002290. Published online.

\section{AUTHOR-RECOMMENDED INTERNET RESOURCES}

Fungal Genome Size database: www.zbi.ee/fungal-genomesize Sanger Institute Pfam database: pfam.sanger.ac.uk 